Click www.researchjournal.co.in/online/subdetail.html to purchase.

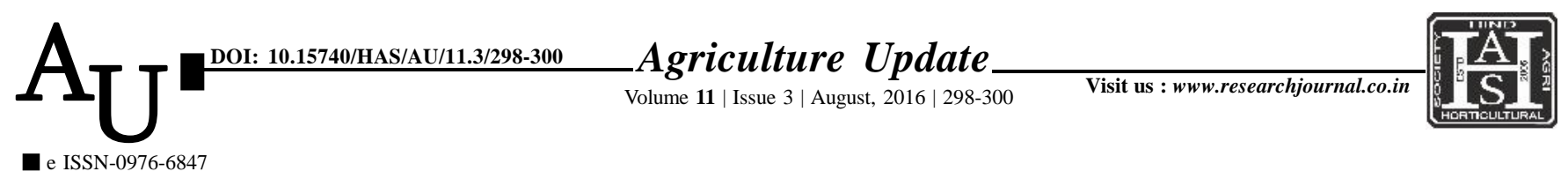

\title{
Research автіcle: Attitude of beneficiares towards agricultural technology management agency
}

\author{
B.M. GONSHETWAD, S.U. MOKHALE, KAPIL JAT AND A.N. DESHMUKH
}

Article Chronicle: Received : 22.06.2016;

Revised :

09.07.2016;

Accepted :

20.07.2016

KEY WoRDS :

Attitude, ATMA,

Benefit availed,

Interest group,

Committee

Author for correspondence :

\section{S.U. MOKHALE}

Department of Extension

Education, Shri Shivaji

Agriculture College,

AMRAVATI (M.S.) INDIA

See end of the article for

authors' affiliations
SUMMARY : The present study on attitude of beneficiaries towards agricultural technology management agency was conducted in the year 2015-16 in Amravati and Bhatkuli tehsil of Amravati district. For this study 100 beneficiaries were selected with the help of random sampling method. The data were collected with the help of structured interview schedule. Collected data were carefully examined, classified quantified and tabulated. Frequencies, mean, standard deviation, co-efficient of correlation of analysis were employed for interpreting the results. Majority of the respondents $(49.00 \%)$ were found in the middle age group i.e. 36 to 50 years. Majority of the respondents $(32.00 \%)$ were higher school level $8^{\text {th }}$ to $10^{\text {th }}$. Majority of the respondents (37.00\%) were in small 1.01 to 2.00 ha category of land holding. Majority of the respondents $(25.00 \%)$ were in medium 50,001 to 1,00,000 category of annual income. Majority of the respondents $(51.00 \%)$ were from medium social participation group. Majority of the respondents $(59.00 \%)$ were from medium level extension contact. Majority of the respondents $(71.00 \%)$ were from medium level socio-economic status. Majority of the respondents $(76.00 \%)$ were from medium mass media exposure. Majority of the respondents $(67.00 \%)$ were from medium benefits availed. Majority of the respondents (44.00\%) were from neutral attitude towards agricultural technology management agency. Majority of respondents $(52.00 \%)$ reported that the technology provided by ATMA is costly was the main problem. Majority (44.00\%) of the beneficiaries had neutral attitude towards agricultural technology management agency. Information regarding the relationship between the independent and dependant variable the data were subjected to correlation analysis. It was observed that education (0.233), land holding (0.225), had positive and significant relationship with attitude of beneficiaries at 0.05 level of significant towards ATMA. and extension contact (0.346), mass media exposure (0.281), and benefits availed ( 0.476$)$ had positive and significant relationship with attitude of beneficiaries at 0.01 level of significant towards ATMA and annual income (0.029), socio-economic status (0.147) were positively non-significant whereas age (-0.013), social participation (-0.025) showed the negative and non significant relationship with attitude of beneficiaries towards ATMA. The data indicated that most of beneficiaries (52.00\%) reported that the technology provided by ATMA is costly which was the main problem.

How to cite this article : Gonshetwad, B.M., Mokhale, S.U., Jat, Kapil and Deshmukh, A.N. (2016). Attitude of beneficiares towards agricultural technology management agency. Agric. Update, 11(3): 298-300, DOI : 10.15740/ HAS/AU/11.3/298-300. 